\title{
Personnel as a Factor of Production in Development of Regional Tourism Economy - a Conceptual Paper
}

\section{Aleksander Panasiuk*}

\begin{abstract}
Tourism economy appears in every sphere of economy: production of goods and services, their division, exchange and consumption; it also occurs in the majority of the national economy branches that directly or indirectly deal with meeting tourist demand. The majority of economic processes in tourism sector are realized by direct tourism economy and its representatives, tourist entrepreneurs. Territorial selfgovernment units and tourist organizations play a significant role in formation of economic processes in tourism sector on the regional and local levels. The classic economy distinguishes three basic production factors: labor, land and capital. In the modern approaches they are completed with the fourth that has different names. Beginning with technical and organizational progress which is a logic extension of coexistence and cooperation of three basic factors, ending with information and knowledge - treated as the most modern factors of production in the so-called new economy. In the totality of activities of tourism economy entities, a special role should be ascribed to the personnel, namely human potential of tourism economy entities.

Keywords: factors of production, personnel, regional tourism economy.
\end{abstract}

\section{Introduction}

Tourism economy appears in every sphere of economy: production of goods and services, their division, exchange and consumption; it also occurs in the majority of the national economy branches that directly or indirectly deal with meeting tourist demand. In a system approach, tourism economy is defined as a system of correlations emerging during the process of fulfilling tourist's needs, correlations between institutions and organizations realizing the process (Nowakowska, 1988, pp. 169-171). This system includes all activities aimed at meeting touristic demand, from a natural environment adaptation to the needs of touristic movement to creating conditions enabling tourism development.

Tourism economy is one of the elements of national economy structure, which penetrates other sectors and is supported by other economic sectors.

\footnotetext{
* Aleksander Panasiuk, PhD., Associate Professor, University of Szczecin, Management and Services Economics Faculty, Tourism Management Department, ul. Cukrowa 8, Szczecin, Poland, aleksander.panasiuk@wzieu.pl.
} 
The majority of economic processes in tourism sector are performed by direct tourism economy and its representatives, touristic entrepreneurs. Territorial self-government units and tourist organizations play a significant role in formation of economic processes in tourism sector on the regional and local levels.

State, understood as a set of political institutions that operate in relation with civil society, is a regulator of tourism economy processes. In that approach, the term state comprises the whole system of exercising public power, a system that mainly consists of elected politicians and entities of public sector (state's institutions) (Pender and Sharpley, 2005, p. 270).

In the totality of activities of tourism economy entities, a special role should be ascribed to the personnel, namely human potential of tourism economy entities. The aim of this publication is to present the role of personnel in development of regional tourism economy and an indication of the human relationship models.

\section{Production factors in tourism economy}

As in the whole economy, production factors are essential for realization of final effects also in the tourism sector. Production factors are all inputs involved in the production of goods and services. The classic economy distinguishes three basic production factors: labor, land and capital. In the modern approaches they are completed with the fourth one that has different names (Sullivan, 2003, p. 4), ranging from technical and organizational progress which is a logical extension of coexistence and cooperation of three basic factors, to information and knowledge - treated as the most modern factors of production in the so-called new economy (Filipiak and Panasiuk, 2008, pp. 127-129).

Figure 1 presents a system of production factors in the tourism economy (Panasiuk, 2011, p. 91) Considerations taken up in this paper refer to the relations between two, from those presented in the figure 1, production factors in tourism economy:

- labor - personnel employed in the tourist companies, employees responsible for tourism in the territorial self-government units, employees of regional tourist organizations and other tourist organizations and associations operating in region,

- information, knowledge, innovations, which are direct factors of the development of regional tourism economy. 


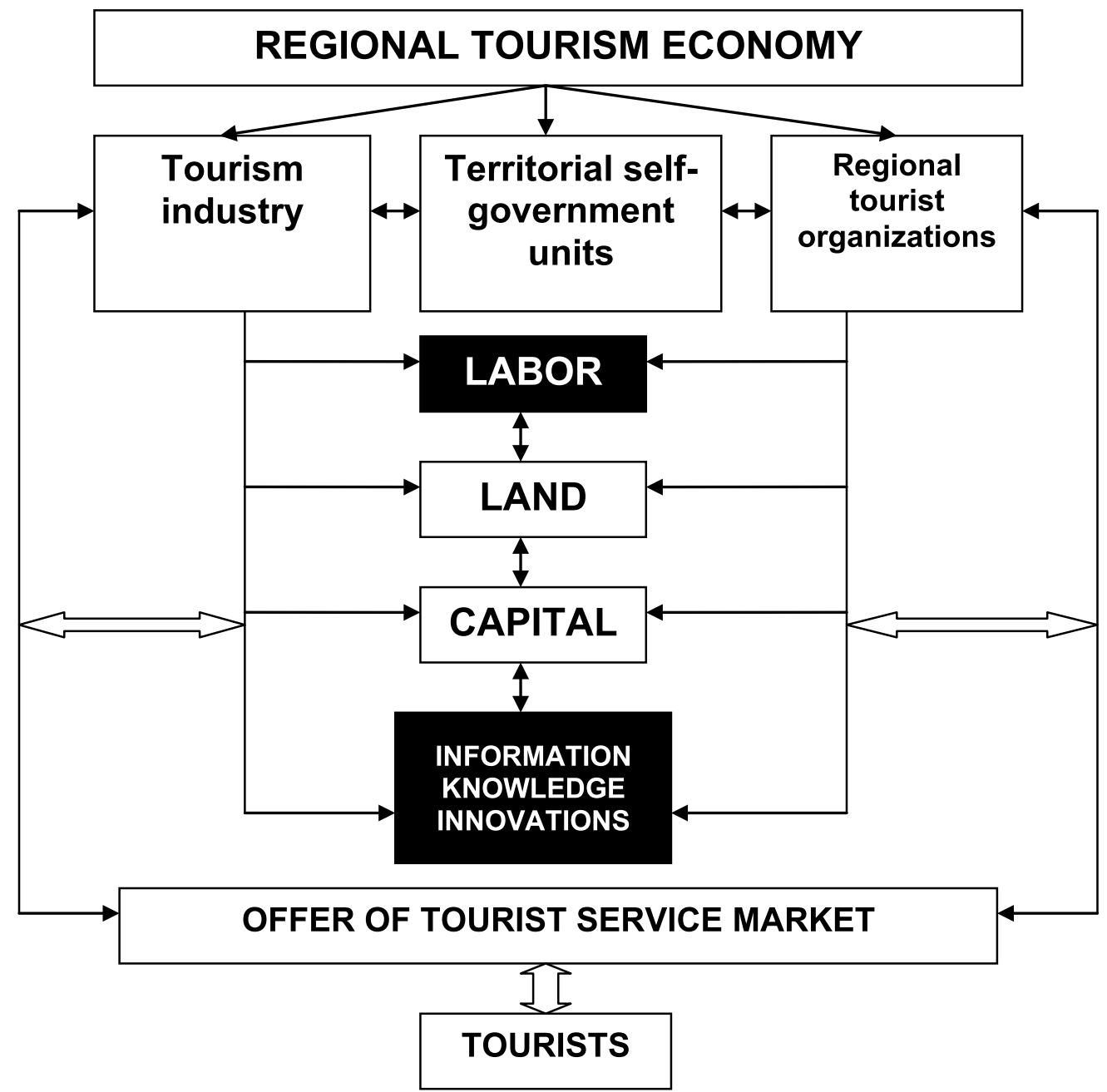

Figure 1. Relations in the structure of production factors of regional tourism economy

\section{Personnel in tourism}

Human factor plays a significant role in services, what distinguishes this sphere of economy among the others (Riley, 1996). Number and qualifications of employees are basic indicators of the level of services supply. Value of work is a dominating element of cost structure in most services, especially in entities providing services. It should also be underlined that services usually require highly qualified work, more complicated than most areas of material production. Real situation on the service market can be judged through the prism of changes in the sphere of employment (Panasiuk, 2002, pp. 82-85).

In the tourism sector, potential of labor is formed by employees of particular entities, especially of tourist companies (Tokarz, 2008, pp. 32-33) and territorial self-government units.

In case of companies - labor is human's intentional operation consisting in changing natural goods and adjusting them to fulfilling human's needs, 
which is usually paid. It can be considered in a quantitative approach as well as qualitative one. The employment rate is used in quantitative estimation while education and seniority are taken into consideration in qualitative estimation. Company should employ the right number of suitably qualified personnel in order to operate effectively in the market economy.

Activities related to the operation of direct tourism economy are mainly taken up by: companies' owners, managers and units' directors. This personnel creates the scope of cooperation with other participants of supply side of the tourism market and they take part in tasks initiated by territorial self-government and tourist organizations. The accomplishment of exploitive tasks lies in the competences of front personnel and influences the extent in which tourists' needs are satisfied (Panasiuk, 2008a, pp. 151-157).

Beside personnel of entities providing tourist services, employees of territorial self-government have significant influence on the shape of regional tourism economy. They are responsible for the range of creation of tourist function. Their competences refer mainly to the municipal and city areas and regions (self-government voivodeships). Among basic competences of employees of units responsible for tourism development are: influencing creation of local infrastructure including tourist tracks, tourist information, tourism promotion, events organization, cooperation with other entities (entrepreneurs and organizations).

Affecting development of local and regional tourism economy lies within the competences of self-government authorities: commune heads, mayors, presidents and marshals and councils of all levels. Effects of their activities are: description of tourism development strategy, conducting tourism policy, current decisions and direct cooperation with representatives of other entities, inter alia within the operation of local and regional tourist organizations.

Significant competences in the field of regional tourism economy are also possessed by the representatives of tourist organizations (managements) including local, regional and also tourist sector self-government. It should be assumed that the basic range of competences of tourist organizations' personnel is related to engaging in wide cooperation with representatives of other institutions and companies in local, regional, domestic and international dimension. Cooperation is concentrated on joint initiatives related to the creation of tourist products, financing those activities, tourism promotion etc.

The final effect of tourist personnel operation is an integrated tourist product, which is a result of joint activities based on the agreement and seeking for joint benefits for entities of supply side of tourism market, considering needs of tourists arriving in tourist destinations. 


\section{Information, knowledge, innovations in tourism economy}

The last production factors presented in Figure 1 is information/knowledge/ innovations. In the modern economy this factor, used in economic processes, determines social and economic development (Dewan and Min, 1997). Its significant influence is visible especially in the long term. It is the resources of that factor not the natural resources that determine the economic position of a particular national economy.

Broadly understood information including aspects of knowledge and innovations becomes a basic production resource in economic processes. Not every item of information appearing in the economy is a production factor. A production factor is only that kind of information that has features of an economic resource. Information economic resources are all potentially useful sets of information, gathered and stored in time, place and by means of technologies and by organizations enabling their utilization by final users operating as economic entities in the economy. In other words, a production factor is knowledge about how to utilize labor, land and capital in order to provide services.

In the conditions of tourist services market, information is utilized as:

- knowledge, namely potential which should be properly managed,

- basis for taking up market decisions, by means of market researches aimed at competition and consumers,

- data base on potential of tourist areas (tourist virtues, tourism infrastructure, entities' tourist offer),

- form (technology) of contact, offer presentation and finalizing transactions with consumers and partners by means of modern reservation systems and the Internet,

- subject of entities' operation on tourism market, especially services in the field of tourist information in a wide meaning.

Without current and reliable information clients would have limited possibilities of developing their tourist needs and finding offers fulfilling those needs. On the other hand, entities offering tourist services would not be able to create tourist offers and effectively launch them on the market.

From the point of view of tourism economy entities, information is an element of an economic process thanks to which it is possible to take fast and effective market decisions in contacts with clients and partners. It allows tourism economy, in aerial approach, to form the whole processes of tourist products creation, their market identification, image creation and integration of cooperation between particular entities of tourism economy: entrepreneurs, self-government units, tourist organizations. One of the most significant issues in that field will be an activity related to the research projects with participation of tourism sector entities, territorial self-government 
and other institutions aiming at development of local and regional tourism economy (including scientific units).

Information, thus, is entrepreneurs' tool by means of which it is possible to take decisions about changes in the company. A pre-condition for implementing changes is entrepreneurship. Entrepreneur creates innovative (Drucker, 1992, p. 29) atmosphere and necessary structures gaining knowledge and capital. Change in the company becomes innovation in a proper scale only when it is accepted by stakeholders and strengthened in the form of new standard practices, procedures and products. Innovations in services can take the following forms (Gołembski, 2007, p. 62):

- organizing solutions for a new problem, new problems can be formulated by clients or created by innovative service providers who foresee demand changes. Identification of problems can result from the interactions between the provider and the client,

- more effective way of finding solutions to problems known type (changes in methods, processes, technical systems).

The first type of innovation is described as product innovation while the second one as process innovation.

Innovativeness in tourism economy can be expressed by (Page, 2005, p. 267):

- Implementation of new goods and services or improving existing ones, e.g. new forms of hotel guests servicing.

- Implementation of new methods of productions, e.g. low-budget hospitality.

- Opening of new markets for tourist movement from the western countries, e.g. Eastern Europe countries,

- New sources of products supply, e.g. local victuals.

- Creation of the new type of organization, e.g. law cost airlines.

Creation of friendly environment for companies, especially from small and medium-sized enterprises sector (SME) lies within the competences of the institutions of business surrounding. Supporting centers are most often defined as institutions aiming at widely understood entrepreneurship support. The operation of those units consists in (Matusiak, 2005, p. 107):

- supporting entrepreneurship, self-employment, enabling newly created, private companies to start; promotion and improvement of SME competitiveness;

- bringing conditions for the transfer of new technological solutions to the economy and realization of innovative ventures;

- lifting the quality of human resources by education, training and consulting and popularization of positive patterns of action;

- utilization of resources and realization of infrastructural undertakings; 
- creation of network of cooperation and partnership between many entities operating towards the development acceleration, increase of prosperity and wealth of inhabitants (Niedzielski, Dołowy, Milewski and Szostak, 2008).

Cooperation between companies and entities of business surrounding in the aspect of innovative processes leads to the formation of cluster structures. A cluster is a group of companies and related institutions, lying in the geographical neighborhood, operating in a particular field, linked together by similarities and mutually completing. An essential element of cooperation within a tourist cluster is a continuous flow of knowledge and information (Milewski, Panasiuk and Szostak, 2005).

A cluster is a spatial concentration of companies, institutions and organizations mutually linked with expanded net of formal and informal relations, based on joint way of development (e.g. technological, joint target markets etc.), competing and cooperating in some aspects of operation at the same time. A cluster can be a tool of increasing competitiveness and innovativeness of local tourism economies. It is also a kind of not wholly formalized net of economic entities and supporting organizations, linked together by informal exchange of knowledge and information (Polski klaster morski, 2004, p. 4).

From the point of view of tourism economy, an access to the natural resources or existence of specific natural conditions in a particular field of regional economy, is a determining factor for clusters emergence. In case of such a cluster, its important elements are tourist values around which tourism infrastructure is created, infrastructure enabling consumption of benefits related to the utilization of those values. A particular tourist area may have many touristic entities mainly providing tourist services (hotels, entities from the gastronomical sector, tour operators and tourist agents, transport systems entities, entities managing tourist attractions), as well as around - touristic, supporting operation of typical tourist companies (Panasiuk, 2008b).

\section{Author's concept models of personnel relations in tourism economy} The structure of production factors in tourism economy determines its operation. Cooperative relations between representatives of:

- economic entities of direct tourism economy,

- territorial self-government units of every level,

- economic self-government units in tourism,

- regional and local tourist organizations.

are vital in that field. Cooperation generally refers to the following aspects of tourism economy functioning:

- tourist product offer and creation, 
- development of tourism infrastructure, including creation of tourist trails,

- applying for financing, especially for European funds,

- local and regional tourism promotion,

- tourist personnel training,

- over regional, cross- boarding, Euro-regional and international aspects,

- taking up innovative activities.

The basic platform of cooperation are local and regional tourist organizations. It can also refer to the other form of cooperation, e.g. by means of economic self-governments or single initiatives.

Cooperation between representatives of companies, organizations and territorial self-government units comprises mainly activities taken up on the highest level, namely owners and management of economic entities, representatives of self-government authorities, directors of units responsible for creation of tourist product, authorities of economic self-government organizations and tourist associations, regional authorities and local tourist organizations.

The following model concepts of personnel relations on local and regional level are possible:

- model of tight cooperation,

- model of limited cooperation,

- model of disintegration,

- model of competition,

- model of conflict and crisis.

The first model - of tight cooperation is related to the agreement between personnel of particular companies and institutions and to the realization of joint market policy. It consists in good human relations and integration around common goals. In that field, realization of innovative goals in tourism economy is the easiest for tourist staff. In practice, that model can be applied in regional and local tourist organizations, where economic entities, self government entities and organizations are strongly represented and implemented goals reflect interests of surrounding entities and inhabitants as widely as possible. Moreover, their activity is not determined by political goals.

The second model - of limited cooperation is a partial version of the first one. Its existence results from the limited representation of entities involved in tourism economy development, which accounts for the fact that realized tasks do not reflect all interests. This model is the most frequently applied one in the practice of operation of regional tourist organizations in Poland.

The next model - of disintegration consists in the lack of agreement and forms of cooperation between representatives of tourism sector. Activities in the field of tourism economy development are taken up individually by 
representatives of particular entities. That system can be observed in situation when institutional forms of cooperation haven't been established in regions or when there are not enough entities in regional tourist organizations and there are not any certain results of cooperation.

The model of competition can be observed in two situations, namely in conditions of:

- operating and conducting effective activities by regional tourist organizations,

- limited scale of operation of regional tourist organizations or in the situation when an organization has not been established yet.

In both situations, market entities, mainly entrepreneurs but also selfgovernments and tourist organizations, can take up competitive activities related to the chosen aspects of tourist product creation or to all tasks, even competitive to the tasks of an organization they are part of. Examples of those activities refer especially to the competition between tourist entrepreneurs and they aim at winning market share, and in case of self-governments at gaining funds for development. Competing for obtaining the right to implement tasks and their financing can be an example here.

The model of conflict and crisis could be:

- a deepened model of competition followed by representatives of tourist entities concentrating on their own goals and limiting market position of other market participants,

- an obvious action of representatives of companies, self-governments and organizations against representatives of another, it consists in fighting for a position in an environment and especially it refers to the attempts at elimination of activities directed at implementation of innovations in tourism economy (activities taken up by other companies).

It leads to the disintegration of activities directed at the tourism economy development until a crisis in operation of regional tourist organizations and at the end to the limitation of their functions, even to the possible break of their operation.

Undoubtedly, the best effects can be achieved by means of the model of tight operation. From the point of view of market effects, using the model of competition could also be beneficial and it could result in a wider offer with better prices. The model of conflict and crisis, often observed in practice, beside some of its positive effects, in the scale of the whole tourist area, leads to the adverse situation and may cause the damage of other entities' effects and consequently may limit the effectiveness of regional tourism economy operation and limit pro-innovative activities. A basic problem in that field is linking or even identifying the tasks of regional tourist organizations with the tasks of regional self-governments. 


\section{Conclusion}

The above considerations could be a basis for an attempt to describe which model of personnel relations occurs in a regional tourism economy and how the particular model influences innovative processes which are the basis for the development of regional tourism economy. As it results from the above considerations, pro-innovative policy can stimulate full cooperation among the regional tourism economy. A basis for activity is an innovative consciousness, thanks to which it is possible to form competitiveness toward other tourism economies, especially neighboring ones. Knowledge and access to the finance as well as personnel should be ranked as a basic condition for implementation of innovative activities on the regional tourism economy level. From the institutional point of view, pro-innovative activities in regional tourism economy should be led by tourist companies on the micro level and by regional self-government and regional tourist organizations on the macro level. Tourist clusters could be seen as a parallel form to the operation of regional tourist organizations.

\section{References}

Dewan S., Min Ch. (1997). The substitution of information technology for other factors of production: A firm level analysis. Management Science, 43(12).

Drucker P.F. (1992). Innowacje i przedsiębiorczość. Warszawa: PWE.

Filipiak B., Panasiuk A. (Eds.). (2008). Przedsiębiorstwo usługowe. Ekonomika. Warszawa: Wydawnictwo Naukowe PWN.

Gołembski G. (Ed.). (2007). Przedsiębiorstwo turystyczne. Ujęcie statyczne i dynamiczne. Warszawa, PWE.

Matusiak K.B. (Ed.). (2005). Innowacje i transfer technologii. Słownik pojęć. Warszawa: Polska Agencja Rozwoju Przedsiębiorczości.

Milewski D., Panasiuk A., Szostak D. (2005). Zachodniopomorski klaster turystyczny, Szczecin: Uniwersytet Szczeciński, Zachodniopomorska Regionalna Organizacja Turystyczna.

Niedzielski P., Dołowy A., Milewski D., Szostak D. (2008). Innowacyjność $i$ struktury klastrowe $w$ województwie zachodniopomorskim. Turystyka, Szczecin: Wydawnictwo Naukowe Uniwersytetu Szczecińskiego.

Nowakowska A. (1988). Gospodarka turystyczna w ujęciu systemowym. Kraków: Folia Eeconomica Cracoviensia, Vol. XXI.

Page S.J. (2005). Tourism Management. Managing for Change. Oxford: Butterworth-Heinemann.

Panasiuk A. (2002). Personel jako instrument marketingu usług turystycznych. Ekonomiczne Problemy Turystyki, 1. Szczecin: Wydawnictwo Naukowe Uniwersytetu Szczecińskiego. 
Panasiuk A. (Ed.). (2008a). Gospodarka turystyczna. Warszawa: Wydawnictwo Naukowe PWN.

Panasiuk A. (Ed.). (2008b). Hotelarstwo, usługi, eksploatacja, zarzqdzanie. Warszawa: Wydawnictwo Naukowe PWN.

Panasiuk A. (Ed.). (2011). Ekonomika turystyki i rekreacji. Warszawa: Wydawnictwo Naukowe PWN.

Polski klaster morski. Założenia programowe. (2004). Gdańsk: Wydawnictwo Instytutu Polska Sieć Gospodarki Morskiej, p. 4.

Pender L., Sharpley R. (Eds.). (2005). The Management of Tourism. Sage Publications Ltd.

Riley, M. (1996). Human Resource Management in the Hospitality and Tourism Industry. Oxford: Butterworth-Heinemann.

Sullivan A, Sheffrin S.M. (2003). Economics: Principles in Action. New Jersey: Pearson Prentice Hall.

Tokarz A. (2008). Zarzqqdzanie zasobami ludzkimi w sektorze turystycznym. Warszawa: Difin.

\section{Abstrakt (in Polish)}

Gospodarka turystyczna obejmuje niemal każdq sferę gospodarki narodowej: produkcję dóbr i usług, w sferze ich podziału, wymiany $i$ konsumpcji. Występujq̨c w większości branż gospodarki, bezpośrednio i pośrednio oddziałuje na popyt turystyczny. Większość procesów gospodarczych w sektorze turystyki jest realizowanych poprzez bezpośrednie podmioty gospodarki turystycznej i jej przedstawicieli, tj. przedsiębiorców turystycznych. Terytorialne jednostki samorzqdu terytorialnego i organizacje turystyczne odgrywajq istotnq rolę w tworzeniu procesów gospodarczych w sektorze turystyki na szczeblu regionalnym i lokalnym. W ekonomii klasycznej wyróżnia się trzy podstawowe czynniki produkcji: praca, ziemia i kapitał. W nowoczesnych koncepcjach, wyodrębnia się także czwarty, któremu nadaje się różne znaczenia i nazwy, poczqwszy od postępu technicznego i organizacyjnego, który jest rozszerzeniem logiki wspótistnienia i współdziałania trzech podstawowych czynników, kończqc na informacji i wiedzy - traktowanych, jako najbardziej nowoczesne czynniki produkcji w tak zwanej nowej ekonomii. W całości działalności podmiotów gospodarki turystycznej, szczególnq rolę należy przypisać pracownikom, a mianowicie potencjałowi ludzkiemu podmiotów gospodarki turystycznej.

Słowa kluczowe: czynniki produkcji, personel, regionalna gospodarka turystyczna. 